\title{
IDENTIFIKASI PSIKOLOGIS IBU NIFAS DENGAN HUMAN IMMUNODEFICIENCY VIRUS (HIV) DI CILACAP
}

\author{
Susilawati $^{1)}$, Majestika Septikasari ${ }^{2)}$ \\ ${ }^{1}$ susilawatimdf@gmail.com, 2jeaflava@gmail.com \\ ${ }^{1,2}$ Program Studi DIII Kebidanan \\ STIKES Al-Irsyad Al-Islamiyyah \\ Jl. Cerme No. 24 Sidanegara Cilacap
}

\begin{abstract}
Abstrac
Postpartum mothers can experience psychological disorders. Psychological disorders of postpartum mothers with HIV will increase and increase. Psychological disorders can interfere with postpartum activities and reduce quality of life. The purpose of the study was to identify the psychological postpartum mothers with human immunodeficiency virus (HIV) in Cilacap. This research was conducted in Cilacap Hospital. This type of research is an inductive qualitative approach. Analysis of qualitative data with contentanalysis technique. The results obtained there are 6 themes of discussion, namely: Labor, Conditions at delivery and birth of the baby, Giving ASI, Family support during childbirth and childbirth, Impairment during childbirth and Feelings when going to raise a child. The results of the study show that there are psychological changes in HIV mothers who give birth to their children. It is necessary to carry out periodic follow-up research yearly to identify psychologically postpartum mothers with HIV each year
\end{abstract}

Keywords: HIV, childbirth, postpartum, psychological

\begin{abstract}
Abstrak
Ibu nifas dapat mengalami gangguan psikologis. Gangguan psikologis ibu nifas dengan HIV akan semakin banyak dan semakin meningkat. Gangguan psikologis dapat mengganggu aktifitas pada ibu nifas dan menurunkan kualitas hidup. Tujuan penelitian untuk mengidentifikasi psikologis ibu nifas dengan human immunodeficiency virus (HIV) di Cilacap. Penelitian ini dilakukan di RSUD Cilacap. Jenis penelitian ini adalah kualitatif pendekatan induktif. Analisa data kualitatif dengan teknik contentanalysis. Hasil diperoleh ada 6 tema pembahasan yaitu: Proses persalinan, Kondisi saat persalinan dan kelahiran bayi, Pemberian ASI, Dukungan keluarga saat bersalin dan nifas, Gangguan masa nifas dan Perasaan saat akan membesarkan anak. Dari hasil pnelitian menunjukan adanya perubahan psikologis pada ibu HIV yang melahirkan anaknya. Perlu penelitian lanjutan yang bersifat periodik tahunan untuk mengidentifikasi psikologis ibu nifas dengan HIV tiap tahun
\end{abstract}

Kata kunci: HIV, nifas, postpartum, psikologis

\section{Pendahuluan}

Masa nifas (puerperium) adalah masa sesudah persalinan dan kelahiran bayi dan masa pulih kembali, mulai dari persalinan selesai sampai alat-alat kandungan kembali seperti sebelum hamil yang memerlukan waktu bervariasi antara 6-12 minggu. Selama masa nifas akan terjadi berubahan fisiologis tubuh dan akan terjadi berubahan psikologis ibu terhadap adanya bayi yang dilahirkannya. ${ }^{1}$ Dalam memberikan pelayanan pada masa nifas secara umum atau ibu nifas dengan HIV, bidan menggunakan asuhan yang berupa memantau keadaan fisik, psikologis, spiritual, kesejahteraan sosial ibu/keluarga, memberikan pendidikan dan penyuluhan secara terus menerus. Pada masa nifas, ibu nifas menjadi sangat sensitive. Peran bidan sangat penting dalam hal memberi pengarahan pada keluarga tentang kondisi ibu serta pendekatan psikologis yang dilakukan bidan pada ibu nifas agar tidak terjadi perubahan psikologis yang patologis. Setelah proses kelahiran tanggung jawab keluarga bertambah dengan hadirnya bayi yang baru lahir, dorongan serta perhatian anggota 
keluarga lainnya merupakan dukungan positif bagi ibu. ${ }^{[1]}$

Dalam menjalani adaptasi setelah melahirkan, secara teori ibu akan melalui fase-fase taking in, fase taking hold, fase letting go. Dalam setiap fase ibu dapat mengalami gangguan psikologis. Secara umum berbagai penyebab ibu nifas mengalami gangguan psikologis meliputi berbagai perubahan yang terjadi dalam tubuh wanita selama kehamilan dan perubahan cara hidupnya sesudah mempunyai bayi, perubahan hormonal, adanya perasaan kehilangan secara fisik sesudah melahirkan yang menjurus pada suatu perasaan sedih. Penyebab yang menonjol adalah kekecewaan emosional yang mengikuti rasa puas dan takut yang dialami kebanyakan wanita selama kehamilan dan persalinan, rasa sakit pada masa nifas, kelelahan karena kurang tidur selama persalinan, kecemasan ketidakmampuan merawat bayi setelah pulang dari rumah sakit, rasa takut tidak menarik lagi bagi suami. ${ }^{[2]}$

Pada ibu nifas dengan HIV maka kemungkinan untuk tidak memberikan ASI pada anaknya akan semakin lama dibanding ibu nifas yang normal, serta lebih beresiko peningkatan angka mortalitas pada ibu nifas, hal tersebut akan meningkatkan gangguan psikologis pada ibu nifas dengan HIV. ${ }^{[3]}$ Hasil penelitian Kuhn et (2005) tentang beberapa masalah pada ibu nifas dengan penyerta HIV diantaranya adalah gangguan psikologis seperti kekhawatiran akan resiko infeksi pada anaknya, gangguan pada menyusui anaknya dan kekhawatiran akan kematian dirinya ${ }^{[4]}$, demikian juga penelitian menjelaskan bahwa penderita HIV akan memiliki masalah dengan psikososial dan kehidupan seksual yang dilakukannya.Studi metaanalisis oleh Brandt (2008) menjelaskan bahwa penderita HIV akan memiliki masalah psikologis seperti: depresi, psychiatric morbidity, anxiety, quality of life, psychological distress, postnatal depression, neurofunction. ${ }^{[5]}$

Gangguan psikologis ibu nifas ini apabila tidak ditangani secara tepat dapat menjadi lebih buruk atau lebih berat. Oleh karena itu penting sekali bagi seorang bidan untuk mengetahui gejala dan tanda dari post partum blues sehingga dapat mengambil tindakan mana yang dapat diatasi dan mana yang memerlukan rujukan kepada yang lebih ahli dalam bidang psikologi. ${ }^{[6]}$

Menurut data Kemenkes RI sejak tahun 2005 - 2015, salah satu propinsi dengan angka kejadian HIV tertinggi adalah Jawa Tengah sebanyak 12.267 kasus. Di Kabupaten Cilacap sendiri pada tahun 2013 - 2016 terdapat angka kejadian HIV sebanyak 319 kasus, dan 42 kasus diantaranya terjadi pada ibu hamil (VCT RSUD Cilacap, 2016). Penelitian ini merupakan penelitian awal untuk mengidentifikasi psikologis ibu nifas dengan riwayat HIV di wilayah Cilacap. Berdasarkan latar belakang tersebut masalah penelitian yang dirumuskan adalah "Identifikasi psikologis ibu nifas dengan HIV di Cilacap?"

\section{Metode Penelitian}

Penelitian dilakukan di RSUD Cilacap. Jenis penelitian kualitatif dengan pendekatan induktif. Panduan wawancara, catatan dan juga tape recorder digunakan untuk untuk pengambilan data. Pengambilan data dengan In-Depth Interview.Sampel penelitan ibu dengan HIV yang pernah mengalami persalinan anaknya, baik spontan atau SC. Dengan kriteria inklusi informan adalah ibu dengan HIV yang pernah mengalami persalinan dalam jangka waktu terdekat dengan waktu penelitian, masih dalam kondisi cukup sehat, bisa berkomunikasi dengan baik, tinggal di wilayah Cilacap.Analisa data kualitatif dengan teknik contentanalysis. Dalam penelitian ini menggunakan teknik triangulasi untuk memeriksa keabsahan data. 


\section{Hasil dan Pembahasan}

Informan berjumlah 2 orang: informan pertama berusia 38 tahun, berpendidikan SD, beragama islam, sebagai IRT, riwayat menikah 2 kali, jumlah anak hidup 4, dan riwayat HIV sejak tahun 2013. Informan kedua berusia 27 tahun, berpendidikan SMA, beragama islam, sebagai IRT, riwayat menikah 2 kali, jumlah anak hidup 1, dan riwayat HIV sejak tahun 2014.

Dari hasil analisis kata kunci diperoleh 6 tema yang berhubungan dengan psikologis ibu nifas dengan HIV yaitu:

a. Proses persalinan

b. Kondisi saat persalinan dan kelahiran bayi

c. Pemberian ASI

d. Dukungan keluarga saat bersalin dan nifas

e. Gangguan masa nifas

f. Perasaan saat akan membesarkan anak

Pembahasan Penelitian:

Proses persalinan. Semua informan menjelaskan bahwa proses persalinan dilakukan secara SC. Hal tersebut sesuai dengan prosedur medis bahwa proses persalinan ibu dengan HIV harus dilakukan dengan prosedur operasi SC untuk menurunkan transmisi secara vertical ke bayi yang dilahirkannya. Sesuai dengan riset penelitian klinik yang dilakukan membuktikan persalinan pada ibu dengan HIV menunjukan bahwa pada bayi yang dilahirkan dengan cara SC transmisi vertikal HIV adalah $1.8 \%$ sedangkan yang lahir per vaginam transmisi vertikal adalah $10.6 \%$. Pertolongan persalinan sebaiknya oleh tenaga kesehatan yang terampil dengan meminimalkan prosedur yang invasif dan menetrapkan universal precaution untuk mencegah transmisi HIV. ${ }^{[7]}$

Hal ini sesuai Montgomery (2003) menyebutkan persalinan pada wanita dengan HIV dianjurkan melalui SC. Persalinan SC elektif yang dilakukan sebelum selaput ketuban pecah dapat menekan risiko penularan dari ibu ke janin pada penderita dengan jumlah viralload diatas $1000 \mathrm{copy} / \mathrm{ml}$. Penelitian Saputri, Niruri, \& Kumara (2013) menunjukkan bahwa ibu yang telah terinfeksi HIV sebelum kelahiran anak dianjurkan untuk memilih persalinan secara SC. Hal ini berdasarkan pertimbangan bahwa proses persalinan merupakan kemungkinan terbesar terjadinya penularan HIV secara vertical, dengan risiko diperkirakan sebesar $10-20 \%$ dari total $45 \%$ risiko transmisi HIV dari ibu ke anak. Penelitian Townsend et al. (2014) juga menyebutkan bahwa persalinan secara sekso sesarea menunjukkan proteksi sebesar 80 - 89\% dalam pencegahan penularan HIV dari ibu ke anak.

Kondisi saat persalinan dan kelahiran bayi. Semua informan menjelaskan bahwa saat persalinan dan kelahiran bayi merasa senang dan bersyukur atas kelahiran bayinya, merasa senang dengan adanya orangtua, saudara dan tetangga yang menjenguk. Seperti pernyataan informan:

“.. sangat bersyukur dapat rejeki lagi dari Allah.."

Ibu HIV positif dalam memutuskan mempunyai anak merupakan keputusan yang kompleks bagi penderita HIV, karena sebagai seorang pengidap HIV yang beresiko menularkan virus kepada bayinya. Namun karena persepsi nilai anak dalam keluarga merupakan nilai yang tinggi sehingga ibu dengan HIV masih tetap memutuskan untuk memiliki anak. Saat proses bersalin, ibu hamil secara umum berharap didampingi oleh suami mereka saat proses persalinan. ${ }^{[1]}$ Ibu hamil akan merasa gembira atas kelahiran bayinya yang ditanggung bersama-sama dengan pasangannya. Suami yang mampu menemani istrinya saat persalinan, ada rasa kebanggaan, kekaguman, kehalusan dan kesukaan yang membuat suami dan istri terasa dekat sekali dan memulai kembali hubungan mereka sebagai suami-istri dan orangtua dengan baik. 
Kelahiran bayi akan berdampak adanya kesenangan, kehormatan / rasa bangga dan hiburan. Pada umumnya alasan menikah karena dorongan keibua. Pada umumnya wanita yang merasa puas dengan perkawinannya, lebih menempatkan anak sebagai prioritas utama sebagai sumber kepuasan, sedangkan hubungan suami istri menempati prioritas rendah. Demikian halnya pada Ibu HIV positif dalam menghadapi anggota keluarga baru tetap akan memiliki perasaan senang, bangga dan bahagia.

Pemberian ASI. Semua informan menjelaskan bahwa ASI berproduksi sedikit, berefek badan terasa lemas, serta menjelaskan tidak akan memerikan ASInya kepada anaknya, dan tidak ada upaya untuk menghentikan ASI secara medis. Semua informan menjelaskan melakukan penggantian ASI dengan memberikan susu formula kepada anaknya. Seperti pernyataan informan: "... saya kasih susu formula..."

Transmisi HIV dari ibu dengan HIV positif ke bayi disebut transmisi vertikal dapat terjadi melalui plasenta pada waktu hamil (intrauterin), waktu bersalin (intrapartum) dan pasca natal melalui air susu ibu (ASI). Telah diketahui bahwa ASI mengandung virus HIV dan transmisi melalui ASI adalah sebanyak $15 \%$. Kemungkinan transmisi vertikal intrapartum dapat diturunkan sampai 2$4 \%$ dengan menggunakan cara pencegahan seperti pemberian antiretrovirus, persalinan secara SC, maka sebaiknya bayi tidak mendapat ASI. Penelitian Saputri (2013) menunjukkan seluruh anak yang lahir dari ibu dengan positif HIV diberikan formula eksklusif, yaitu hanya diberikan susu formula tanpa cairan atau makanan padat pada usia $0-6$ bulan. Hal ini berdasarkkan pertimbangan bahwa pemberian susu formula memiliki risiko minimal $(0 \%)$ untuk penularan HIV dari ibu ke bayi, sedangkan pemberian ASI eksklusif dan makanan campuran (campuran ASI dengan makanan atau cairan lain) berkaitan dengan risiko penularan HIV berturut-turut sebesar 5 $15 \%$ dan $24.1 \% .^{[9]}$

Penderita HIV dapat melakukan alternative pemberian makan pada bayinya dengan beberapa hal berikut: Bila ibu memilih tidak memberikan ASI maka ibu diajarkan memberikan makanan alternatif yang baik dengan cara yang benar, misalnya pemberian dengan cangkir jauh lebih baik dibandingkan dengan pemberian melalui botol. Semua informan menjelaskan merasa bahagia dan senang saat dilakukan pemeriksaan HIV pada anaknya yang hasilnya negative. Anak dari ibu penderita HIV perlu beberapa tindakan dan upaya untuk menghindari anak tidak terular HIV dari orangtuanya dengan berbagai macam tindakan seperti upaya supportif dan dukungan, pemberian imunisasi rutin, pemantauan pertumbuhan dan pemeriksaan darah. Sehingga bila timbul gejala dapat segera diobati dengan antiretroviral. ${ }^{[12]}$ Sehingga bila anak negative maka orangtua akan lebih bahagia melihat kondisianaknya sehat. Semua informan merasakan perubahan psikologis yang negative akibat tidak dapat memberikan ASI-nya kepada anaknya, seperti munculnya perasaan sedih, stress, cemas, merasa bersalah terhadap diri sendiri serta merasa takut. Menyusui merupakan salah satu tugas perkembangan perempuan setelah melahirkan. Tidak semua perempuan dapat melewati tugas tersebut dengan baik karena berbagai kondisi, salah satu kondisi tersebut adalah karena ibu menderita HIV. Kondisi ini tidak hanya berdampak pada kesehatan bayi tetapi pada beberapa perempuan juga dapat mengganggu konsep diri sebagai ibu, karena tidak dapat berperan optimal dalam perawatan kesehatan bayinya. Gangguan psikologis berupa gangguan konsep diri yang dialami perempuan pada usia produktif sering berhubungan 
dengan perannya sebagai isteri, ibu dan pekerja. Sehingga beberapa ibu akan mengalami gangguan psikologis seperti perasaan sedih, bersalah dan kecewa pada diri sendiri. ${ }^{[13]}$

Dukungan keluarga saat bersalin dan nifas. Semua informan merasa mendapat dukungan fisik dari kelurga saat bersalin dan saat periode nifas, baik dari suami, anak maupun dari saudara. Seperti pernyataan informan:

“..suami, anak dari suami pertama saya dan saudara saya mendampingi.."

Semua informan juga memperoleh dukungan ekonomi oleh anggota keluarga yang lain.

“..ya kadang berapa bulan saudara ya ngasih buat beli susu.."

Menurut Ed, Gates, Gj, \& Sakala (2013), suami dapat menjadi sumber kekuatan, kesenangan dan dorongan yang penting, suami dapat ikut merasakan kecemasan dan antisipasi kehamilan dengan maksud untuk mengambil bagian aktif dalam persalinan maupun untuk menjadi seorang ayah. Suami hadir untuk mendukung atau berbuat sesuatu untuk membantu. Dengan menunjukkan sikap sabar dalam menemani istri, ia dapat meredakan suasana tegang dan mendukung gambaran diri istri tentang diri sendiri telah melakukan tugas mulia. $[15,16]$

Pada awal persalinan, partisipan mengalami stres dan kesulitan mengurus bayi, tapi bisa beradaptasi. Ada juga partisipan yang tidak mengalami stres dan kesulitan mengurus bayi karena terus dibantu, didampingi oleh suami dan keluarganya serta pengalaman mengurus anak sebelumnya. Hal ini sesuai dengan pernyataan Girgis, George, \& Anderson (2011) yang menyatakan bahwa pengalaman saat menjadi orangtua terdiri dari adaptasi terhadap identitas peran yang baru bagi orangtua dan anggota keluarga.

Sumber dukungan keluarga merupakan dukungan yang mudah diperoleh dan sesuai dengan nilai dan norma sehingga pemberiannya dapat dilakukan kapan dan dimanapun. Dampak dari dukungan keluarga yang dirasakan ibu yang terdeteksi HIV adalah perasaan bahagia, membangkitkan semangat hidup, perasaan lebih tenang dan terbantu dalam perawatan selama persalinan. Hal ini sejalan dengan penelitian Chen, Hedrick, \& Young (2010) yang menyatakan bahwa dukungan keluarga memiliki pengaruh yang signifikan terhadap status kesehatan, rasa percaya diri dalam pengambilan keputusan dan isolasi sosial.

Satu informan memperoleh dukungan psikologis secara verbal oleh saudara yang berdomisi jauh dari informan. Dukungan keluarga meski dalam bentuk komunikasi dapat mempengaruhi individu yang dalam proses kelahiran dan bersalin, dukungan sosial diartikan sebagai kesenangan, bantuan, yang diterima oleh seseorang melalui hubungan formal dan informal dengan yang lain atau kelompok. Hal ini juga didukung oleh pernyataan yang menyatakan bahwa peran keluarga adalah peran persaudaraan, suatu bentuk tindakan nyata yang menganggap ibu postpartum sebagai anggota keluarga, dan secara psikologis tetap diperhatikan, disayangi, atau dianggap sebagai bagian dari keluarga. ${ }^{[19]}$

\section{Gangguan masa nifas}

Semua informan menyampaikan tidak ada gangguan fisik saat masa nifas yang terlalu berat hanya sering terjaga malam untuk membuatkan susu anak saja, serta merasa tidak terlalu capai. Berikut pernyataan informan:

"..paling sering terbangun malam hari..”

“..saya yang pengen pipis.."

“..sampai pengen mati saja..."

“.. suami saya mendukung terus untuk taubat sama Allah.."

Satu responden menyampaikan terkadang teringat penyakitnya dan sempat berfikir akan mengakhiri hidupnya. Sedangkan satu responden hanya merasa sedih saat memikirkan 
penyakitnya. Satu responden yang merasa ingin mengakhiri hidupnya merasakan adanya dukungan suami yang terus menerus dan selalu mengingatkan untuk bertaubat sehingga masih bertahan hidup sampai saat ini. Pasca melahirkan ibu akan mengalami beberapa perubahan, baik perubahan fisik maupun perubahan psikologis, seorang ibu akan merasakan gejala gejala psikiatrik setelah melahirkan, beberapa penyesuaian dibutuhkan oleh ibu. Sebagian ibu bisa menyesuaikan diri dan sebagian tidak bisa menyesuaikan diri, bahkan bagi mereka yang tidak bisa menyesuaikan diri mengalami gangguan gangguan psikologis dengan berbagai macam sindrom atau gejala. ${ }^{[20]}$

Proses penerimaan diri pasien HIV tidak terlepas dari faktor-faktor penerimaan diri yaitu pemahaman diri, tidak adanya tekanan emosi yang berat, tidak hadirnya hambatan-hambatan dari lingkungan, konsep diri yang stabil, harapan yang realistis, dan sukses yang sering terjadiProses penerimaan diri pada pasien HIV ini bersifat dinanis, sewatu-waktu dapat berubah. ${ }^{[21]}$

Perasaan saat akan membesarkan anak. Semua informan merasa takut saat akan membesarkan anaknya nanti mengingat kondisi penyakit yang diderita oleh informan tersebut. Dengan menyatakan:

"Ada perasaan takut Bu, saya bisa atau tidak nanti.."

Tumbuh kembang anak merupakan proses utama yang hakiki dan khas pada anak dan merupakan sesuatu yang penting bagi seorang anak. Pada penderita HIV, khususnya yang menjalankan peran sebagai seorang ibu, bisa saja terjadi dampak psikologis akibat gagal dalam memainkan perannya di keluarga untuk membesarkan anaknya. Partisipan dalam penelitian ini mengalami kecemasan selain terkena penyakit HIV/AIDS yang utama ialah perasaan takut akan hasil identifikasi dari pihak rumah sakit diketahui orang banyak. ${ }^{[22]}$

\section{Kesimpulan}

Berdasarkan hasil penelitian pada ibu nifas dengan human immunodeficiency virus(HIV) tentang identifikasi psikologis ibu nifas dengan HIV di Cilacap disimpulkan ada 6 tema pembahasan yaitu: Proses persalinan, Kondisi saat persalinan dan kelahiran bayi, Pemberian ASI, Dukungan keluarga saat bersalin dan nifas, Gangguan masa nifas dan Perasaan saat akan membesarkan anak. Perlu penelitian lanjutan yang bersifat periodik tahunan untuk mengidentifikasi psikologis ibu nifas dengan HIV tiap tahun.

\section{Daftar Pustaka}

[1] Heryani R. Asuhan Kebidanan Ibu Nifas Dan Menyusui. Jakarta: Trans Info Media; 2012.

[2] Wijayanti K, Wijayanti FA, Nuryanti E. Gambaran FaktorFaktor Resiko POstpartum Blues Di Wilayah Kerja Puskesmas Blora. $\boldsymbol{J}$ Kebidanan. 2013;2(5):57-64. ejournal.poltekkessmg.ac.id/ojs/index.php/jurkeb/artic le/download/107/73.

[3] Iliff PJ, Piwoz EG, Tavengwa N V, et al. Early exclusive breastfeeding reduces the risk of postnatal HIV-1 transmission and increases HIVfree survival. AIDS. 2005;19(7):699-708. doi:10.1097/01.aids.0000166093.16 446.c9.

[4] Kuhn L, Kasonde P, Sinkala M, et al. Prolonged breast-feeding and mortality up to two years postpartum among HIV-positive women in Zambia. AIDS. 2005;19(15):1677-1681. doi:10.1109/TMI.2012.2196707.Se parate.

[5] Brandt R. The mental health of people living with HIV / AIDS in 
Africa: A systematic review. CSSR. 2008;(231).

[6] Kirana Y. Hubungan tingkat kecemasan post partum dengan kejadian post partum blues di rumah sakit dustira cimahi. $\boldsymbol{J}$ Ilmu Keperawatan. 2015;III(1):25-37. http://ejournal.bsi.ac.id/ejurnal/inde x.php/jk/article/viewFile/150/115.

[7] De Cock KM, Fowler MG, Mercier E, et al. Prevention of mother-tochild HIV transmission in resourcepoor countries: translating research into policy and practice. Jama. 2000;283(9):1175-1182.

[8] Montgomery KS. Nutrition and HIV-positive pregnancy. J Perinat Educ. 2003;12(1):42.

[9] Saputri LO, Niruri R, Kumara KD. Pelaksanaan Intervensi Pencegahan Penularan HIV Dari Ibu Ke Anak (PPIA) Di RSUP Sanglah Denpasar Tahun 2007-2011. Bali Univ Udayana. 2013.

[10] Townsend CL, Byrne L, CortinaBorja M, et al. Earlier initiation of ART and further decline in motherto-child HIV transmission rates, 2000-2011. Aids. 2014;28(7):10491057.

[11] Safarina L. FAMILY'S LIFE EXPERIENCE IN TAKING CARE CHILDREN WITH HIV/AIDS IN CIMAHI CITY. Indones Nurs J Educ Clin. 2018;1(2):147-155.

[12] Suradi R. Tata laksana Bayi dari Ibu pengidap HIV/AIDS. Sari Pediatr. 2016;4(4):180-185.

[13] Pieter HZ, Psi S, Janiwarti B, Psi S, Saragih NM, Kep S. Pengantar Psikopatologi Untuk Keperawatan. Kencana; 2011.
[14] Ed H, Gates S, Gj H, Sakala C. Continuous support for women during childbirth ( Review ). 2012;(10).

[15] Ed H, Gates S, Gj H, Sakala C. Continuous support for women during childbirth ( Review ). 2013;(7).

[16] Ed H, Downe S, Edwards N, Walsh D. Home-like versus conventional institutional settings for birth ( Review ). 2009;(1).

[17] Girgis S, George RP, Anderson RT. What is marriage. Harv JL Pub Pol'y. 2011;34:245.

[18] Chen Y-M, Hedrick SC, Young HM. A pilot evaluation of the Family Caregiver Support Program. Eval Program Plann. 2010;33(2):113-119.

[19] Gillman RR, Newman BS. Psychosocial concerns and strengths of women with HIV infection: An empirical study. Fam Soc. 1996;77(3):131-141.

[20] Jomeen J, Glover L, Jones C, Garg D, Marshall C. Assessing women's perinatal psychological health: exploring the experiences of health visitors. J Reprod Infant Psychol. 2013;31(5):479-489.

[21] Forstein M, McDaniel JS. Medical overview of HIV infection and AIDS. Psychiatr Ann. 2001;31(1):16-20.

[22] Serovich JM, Kimberly JA, Mosack KE, Lewis TL. The role of family and friend social support in reducing emotional distress among HIV-positive women. AIDS Care. 2001;13(3):335-341. 